Article

\title{
Investigation of Simultaneous Effects of Aerosol Properties and Aerosol Peak Height on the Air Mass Factors for Space-Borne $\mathrm{NO}_{2}$ Retrievals
}

\author{
Hyunkee Hong ${ }^{1}$, Hanlim Lee ${ }^{1, *}$, Jhoon Kim ${ }^{2}$, Ukkyo Jeong ${ }^{3}$, Jaeyong Ryu ${ }^{4}$ and Dae Sung Lee ${ }^{5}$ \\ 1 Division of Earth Environmental System Science Major of Spatial Information Engineering, \\ Pukyong National University, Busan 608-737, Korea; brunhilt77@gmail.com \\ 2 Department of Atmosphere Science, Yonsei University, Seoul 03722, Korea; jkim2@yonsei.ac.kr \\ 3 Earth System Science Interdisciplinary Center, University of Maryland, College Park, MD 20742, USA; \\ ukkyo.jeong@gmail.com \\ 4 Department of Urban Environmental Engineering, Kyungnam University, Changwon 631-701, Korea; \\ ryujaeyong6317@gmail.com \\ 5 Department of Energy \& Mineral Resource Engineering, Dong-A University, Busan 604-714, Korea; \\ leeds@dau.ac.kr \\ * Correspondence: hllee@pknu.ac.kr; Tel.: +82-51-629-6688
}

Academic Editors: Richard Müller and Prasad S. Thenkabail

Received: 3 January 2017; Accepted: 23 February 2017; Published: 25 February 2017

\begin{abstract}
We investigate the simultaneous effects of aerosol peak height (APH), aerosol properties, measurement geometry, and other factors on the air mass factor for $\mathrm{NO}_{2}$ retrieval at sites with high $\mathrm{NO}_{2}$ concentration. A comparison of the effects of high and low surface reflectance reveals that $\mathrm{NO}_{2}$ air mass factor (AMF) values over a snowy surface (surface reflectance 0.8 ) are generally higher than those over a deciduous forest surface (surface reflectance 0.05). Under high aerosol optical depth (AOD) conditions, the aerosol shielding effect over a high-albedo surface is revealed to reduce the path-length of light at the surface, whereas high single scattering albedo (SSA) conditions (e.g., SSA $=0.95$ ) lead to an increase in the aerosol albedo effect, which results in an increased AMF over areas with low surface reflectance. We also conducted an in-depth study of the APH effect on AMF. For an AOD of 0.1 and half width (HW) of $5 \mathrm{~km}, \mathrm{NO}_{2}$ AMF decreases by $29 \%$ from 1.36 to 0.96 as APH changes from 0 to $2 \mathrm{~km}$. In the case of high-AOD conditions (0.9) and $\mathrm{HW}$ of $5 \mathrm{~km}$, the $\mathrm{NO}_{2}$ AMF decreases by $240 \%$ from 1.85 to 0.54 as APH changes from 0 to $2 \mathrm{~km}$. The AMF variation due to error in the model input parameters (e.g., AOD, SSA, aerosol shape, and APH) is also examined. When APH is $0 \mathrm{~km}$ with an AOD of 0.4, SSA of 0.88, and surface reflectance of 0.05 , a $30 \%$ error in AOD induces an AMF error of between $4.85 \%$ and $-3.67 \%$, an SSA error of 0.04 leads to $\mathrm{NO}_{2} \mathrm{VCD}$ errors of between $4.46 \%$ and $-4.77 \%$, and a $30 \%$ error in AOD induces an AMF error of between $-9.53 \%$ and $8.35 \%$ with an APH of $3 \mathrm{~km}$. In addition to AOD and SSA, APH is an important factor in calculating AMF, due to the $2 \mathrm{~km}$ error in APH under high-SZA conditions, which leads to an $\mathrm{NO}_{2} \mathrm{VCD}$ error of over $60 \%$. Aerosol shape is also found to have a measureable effect on AMF under high-AOD and small relative azimuth angle (RAA) conditions. The diurnal effect of the $\mathrm{NO}_{2}$ profile is also examined and discussed.
\end{abstract}

Keywords: $\mathrm{NO}_{2}$; air mass factor; DOAS method; aerosol peak height

\section{Introduction}

Nitrogen dioxide $\left(\mathrm{NO}_{2}\right)$ plays a key role in the photochemistry of tropospheric and stratospheric ozone [1]. Tropospheric $\mathrm{NO}_{2}$ is present in urban and industrialized areas because one of the major sources of tropospheric $\mathrm{NO}_{2}$ is fossil fuel combustion [2] in addition to biomass burning, 
soil emission, and lightning [3]. Since the 1990s, $\mathrm{NO}_{2}$ has been monitored on a global scale by several space-borne sensors: the Global Ozone Monitoring Experiment (GOME) instrument, the Scanning Imaging Spectrometer for Atmospheric Cartography (SCIAMACHY), the Ozone Monitoring Instrument (OMI) and the GOME-2 instrument. Furthermore, observations of diurnal variations in $\mathrm{NO}_{2}$ will be possible with the launch of the Tropospheric Emission: Monitoring Pollution (TEMPO) instrument by the National Aeronautics and Space Administration (NASA) [4], the Sentinel-4 on board the Meteosat Third Generation Sounder (MTG-S) by the European Space Agency (ESA), and the Geostationary environment monitoring sensor (GEMS) on board the Geostationary Korean Multi-Purpose Satellite-2B (GEO-KOMPSAT 2B) by the National Institute of Environmental Research (NIER) of Korea. $\mathrm{NO}_{2}$ is typically measured by satellite sensors using spectral fitting methods such as differential optical absorption spectroscopy (DOAS). $\mathrm{NO}_{2}$ slant column density (SCD), which is the integral of the $\mathrm{NO}_{2}$ concentration present over the path between a light source and the sensor, is usually first retrieved by the DOAS method. The $\mathrm{NO}_{2} \mathrm{SCD}$ is then converted into vertical column density (VCD) by dividing the SCD by the air mass factor (AMF), which is calculated using a radiative transfer model (RTM). However, questions remain about the accuracy of $\mathrm{NO}_{2}$ retrieval using the DOAS method, especially in relation to $\mathrm{NO}_{2}$ AMF errors arising from uncertainties in radiative transfer model input parameters such as the vertical distribution of $\mathrm{NO}_{2}$ and aerosol particles, aerosol physical properties, surface reflectance, and cloud coverage, among other factors. Given the importance of AMF to the accuracy of $\mathrm{NO}_{2}$ retrieval using the DOAS method, previous studies have investigated AMF sensitivity to the effects of aerosol and surface reflectance. Boersma et al. [5] report that in polluted regions, AMF errors in the $\mathrm{OMI} \mathrm{NO} \mathrm{NO}_{2}$ column retrieval over the visible wavelength range (405-465 nm) are $20 \%$, $20 \%$, and $15 \%$, which are induced by uncertainties in the $\mathrm{NO}_{2}$ vertical profile, surface reflectance, and aerosol concentration, respectively. According to Valks et al. [6], AMF errors in the GOME-2 $\mathrm{NO}_{2}$ column retrieval are $15 \%-50 \%$ in polluted regions. Boersma et al. [7] showed that uncertainties in model input parameters (e.g., cloud coverage, surface reflectivity, and a priori $\mathrm{NO}_{2}$ vertical shape) result in reduced accuracy in $\mathrm{NO}_{2}$ AMF calculations. In addition, Leitão et al. [2] carried out an AMF sensitivity study that considered the effects of the $\mathrm{NO}_{2}$ vertical profile, boundary layer height, surface reflectance, AOD, and SSA on $\mathrm{NO}_{2}$ AMF values. However, AMF values commonly change simultaneously with a variety of factors such as aerosol properties (aerosol peak height (APH), AOD, and SSA), surface reflectance, solar zenith angle (SZA), and viewing zenith angle (VZA), especially for high-temporal-resolution observations from geostationary orbit. Furthermore, AMF errors are much larger than the spectral fitting errors $(\sim 10 \%)$ that occur from NO2 cross section uncertainties, spectral calibration uncertainties, instrument noise such as dark current, etc. The details of spectral fitting error sources can be found in previous study $[7,8]$. Thus, the following analyses were carried out as part of the present study.

- An investigation of the simultaneous effects of aerosol peak height (APH), various aerosol properties (e.g., AOD, SSA, and aerosol shape), and geometric information on the AMF for $\mathrm{NO}_{2}$ retrieval.

- A calculation of AMF for specific environmental conditions such as high surface reflectance (snow case) and high APH (Asian dust case).

- A quantification of the diurnal effect of the $\mathrm{NO}_{2}$ vertical profile on AMF calculations for geostationary $\mathrm{NO}_{2}$ measurements.

\section{Methodology}

The AMF definition is the ratio of the $\mathrm{NO}_{2}$ slant column density $\left(\Omega_{\mathrm{S}}\right)$ to the $\mathrm{NO}_{2}$ vertical column density $\left(\Omega_{\mathrm{V}}\right)$, and depends on the radiative transfer properties of the atmosphere such as aerosol, cloud, and $\mathrm{NO}_{2}$ vertical distribution [9]. The equation of $\mathrm{AMF}$ is as follows:

$$
\mathrm{AMF}=\frac{\Omega_{\mathrm{S}}}{\Omega_{\mathrm{V}}}
$$


AMF can be calculated using the scattering weight, $\omega^{\prime}(z)$, and the shape factor $S_{z}^{\prime}(z)$ at each layer [9]. The scattering weight is the sensitivity of the backscattered spectrum to the abundance of the absorber at each layer, while the shape factor is a normalized vertical profile of number density [9]. AMF can be expressed in terms of the scattering weight and shape factor, as follows:

$$
\begin{gathered}
A M F=A M F_{G} \int_{0}^{\infty} \omega^{\prime}(z) S_{z}^{\prime}(z) d z \\
\omega^{\prime}(z)=-\frac{1}{A M F_{G}} \frac{\partial \ln I_{B}}{\partial \tau} \\
\mathbf{S}_{\mathbf{z}}^{\prime}(\mathbf{z})=\frac{\alpha(\mathbf{z}) \mathbf{n}(\mathbf{z})}{\int_{0}^{\infty} \alpha(\mathbf{z}) \mathbf{n}(\mathbf{z}) \mathbf{d z}} \\
\tau=G+R+A
\end{gathered}
$$

where $A M F_{G}$ is the geometric $\mathrm{AMF} ; I_{B}$ represents the backscattered intensity observed by the satellite instrument; $\tau$ is the optical thickness; $\alpha(z)$ and $n(z)$ are the absorption cross-section $\left(\mathrm{m}^{2} \cdot \mathrm{molecules}^{-1}\right)$ and number density (molecules $\cdot \mathrm{m}^{-3}$ ), respectively; $z$ denotes each vertical layer; $G$ is the molecular (trace gas) absorption optical depth; $R$ is the molecular (Rayleigh) scattering optical depth; and $A$ is the aerosol extinction optical depth [10]. In addition to $\mathrm{NO}_{2}$ column density, aerosol extinction vertical shape has an effect on $\mathrm{NO}_{2} \mathrm{AMF}$, as the vertical shape influences the scattering weight at each layer. In this study, AMF was computed using linearized pseudo-spherical scalar and vector discrete ordinate radiative transfer (VLIDORT, version 2.6). A detailed description of VLIDORT and its utilization for AMF calculation is provided by [10]. In the present study, AMF was computed at $440 \mathrm{~nm}$, as the spectral fitting is carried out over a wavelength interval of 430-450 nm where there exist four strong $\mathrm{NO}_{2}$ absorption bands. Figure 1 presents a summary of the AMF computation. We calculated the scattering weight using AOD, SSA, surface reflectance, SZA, VZA, APH and HW, while the shape factor was calculated using the $\mathrm{NO}_{2}$ vertical profile and absorption cross-section. A description of each input parameter follows.

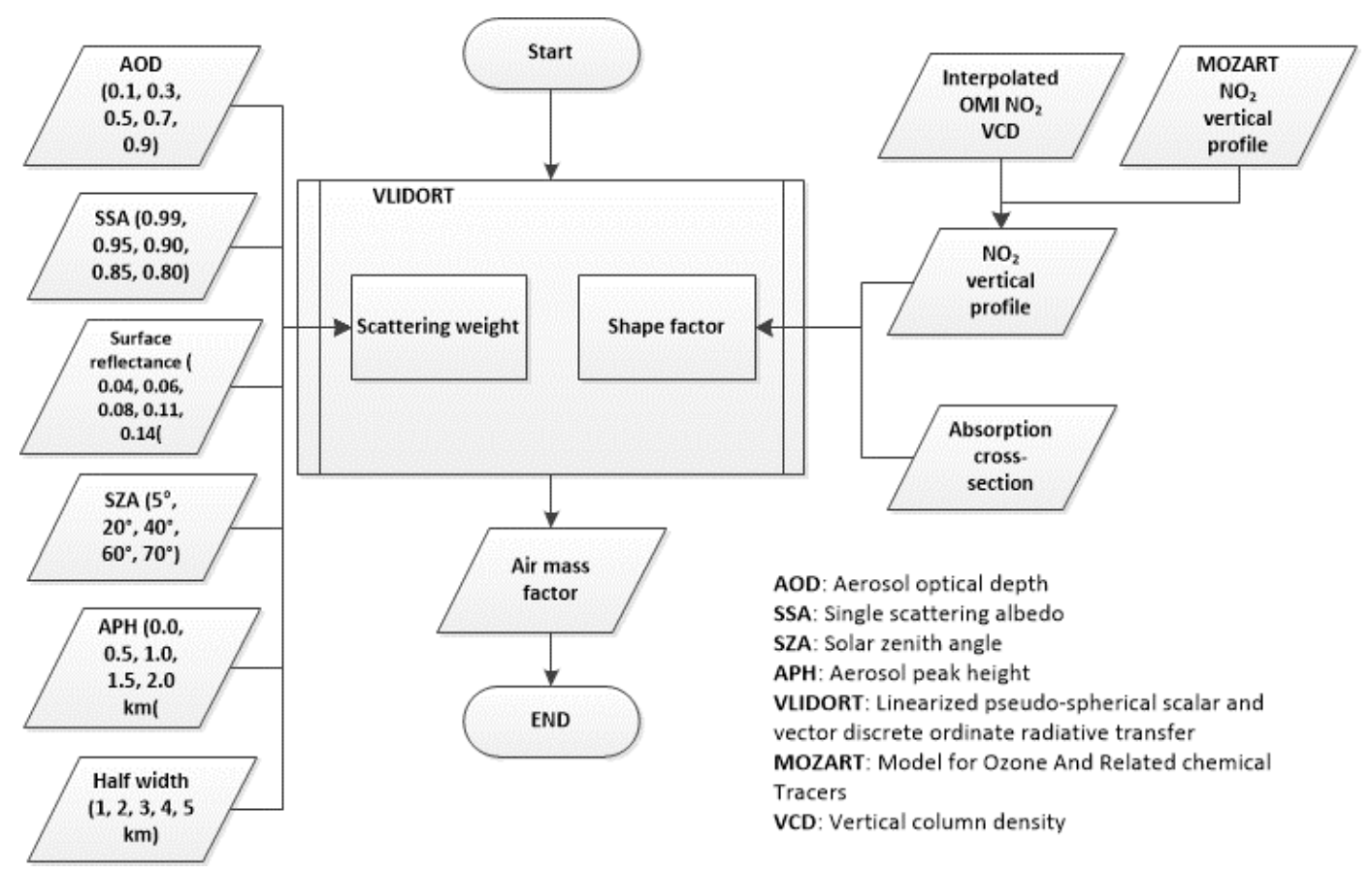

Figure 1. Flow chart of air mass factor (AMF) calculations VLIDORT. 


\section{1. $\mathrm{NO}_{2}$ Vertical Profile}

Figure 2 shows $\mathrm{NO}_{2}$ vertical profiles used as input data for the AMF calculation by: (a) concentration; and (b) mixing ratio. $\mathrm{NO}_{2}$ vertical profiles obtained in Beijing during Dec 2011 from the Model for Ozone And Related chemical Tracers, version 4 (MOZART-4), and $\mathrm{NO}_{2}$ vertical column densities (VCD) for the same month from OMNO2d of the Aura OMI Level-3 Global Gridded Total and Tropospheric $\mathrm{NO}_{2}$ Data Product $\left(0.25^{\circ} \times 0.25^{\circ}\right)$ are used to generate a $\mathrm{NO}_{2}$ vertical profile that represents the high- $\mathrm{NO}_{2}$ site of this study. A detailed description of the emission inventory and chemistry used for the MOZART simulation can be found in [11]. The spatial resolution of the MOZART $\mathrm{NO}_{2}$ vertical profile is $1.89^{\circ}$ latitude $\times 2.5^{\circ}$ longitude and it consists of 56 layers from the surface to $\sim 2 \mathrm{hPa}$. We do not use the unadjusted $\mathrm{NO}_{2} \mathrm{VMR}$ profile from MOZART because the spatial resolution of MOZART is low, but instead calculate a $\mathrm{NO}_{2}$ profile through comparison with the OMI $\mathrm{NO}_{2}$ VCD. The comparison between the tropospheric $\mathrm{NO}_{2}$ VCDs from MOZART and OMI is iterated until the MOZART tropospheric $\mathrm{NO}_{2}$ column equals that of OMI by increasing or decreasing the MOZART $\mathrm{NO}_{2}$ volume mixing ratio at all tropospheric layers by $0.2 \%$ per iteration. The shapes of the MOZART tropospheric $\mathrm{NO}_{2}$ vertical profiles were not changed by this adjustment. Despite the low spatial resolution of MOZART stratospheric $\mathrm{NO}_{2}$ measurements, stratospheric $\mathrm{NO}_{2}$ vertical profiles from MOZART are used without adjustment to represent the stratospheric $\mathrm{NO}_{2}$ in both polluted and background areas because $\mathrm{NO}_{2}$ concentrations are lower and relatively stable in the stratosphere compared with those in the troposphere [12]. The $\mathrm{NO}_{2}$ vertical shape in Beijing, a polluted area, is similar to that of an average urban profile used in a previous study [2] although the magnitude for the Beijing case is larger by a factor of two.
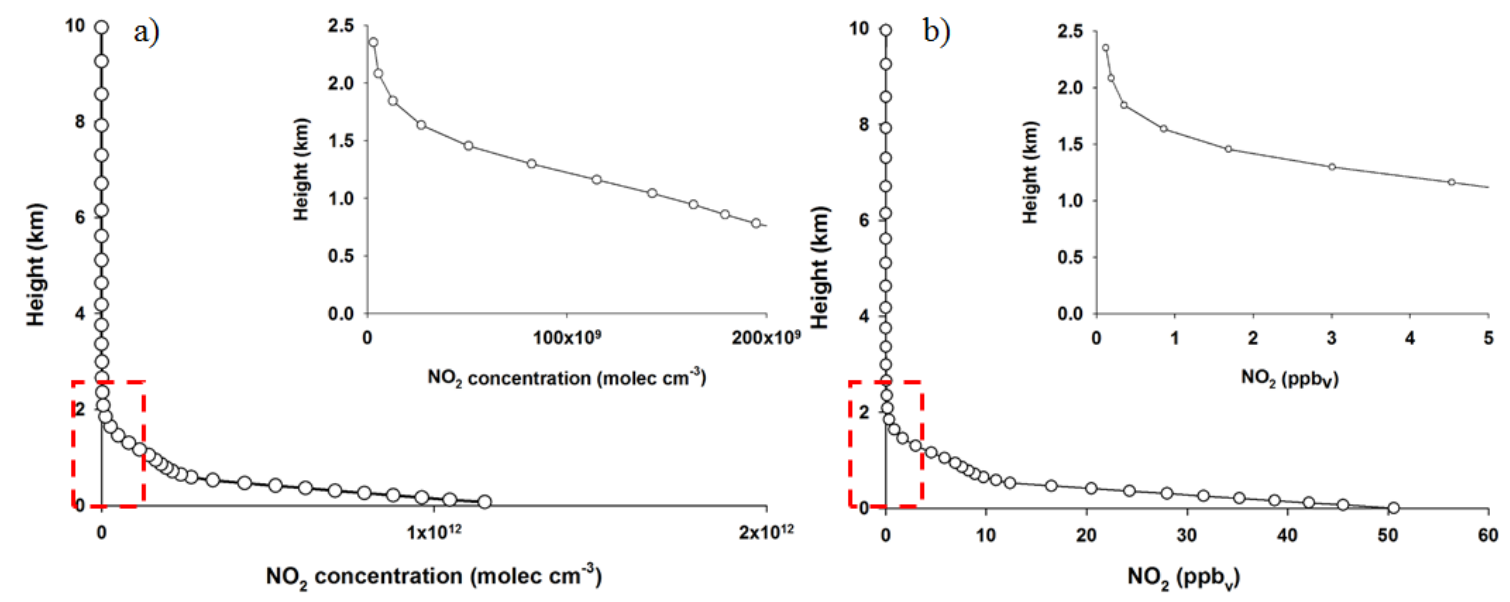

Figure 2. $\mathrm{NO}_{2}$ profile from the surface to $10 \mathrm{~km}$, as obtained from MOZART-4 by: (a) concentration; and (b) mixing ratio.

\subsection{Aerosol Extinction Profile}

To quantify the effects of $\mathrm{APH}$ on $\mathrm{NO}_{2} \mathrm{AMF}$, we used a variety of parameters (AOD, $\mathrm{APH}$, aerosol upper limit, and aerosol lower limit) to calculate the aerosol extinction coefficient profiles used as inputs for the AMF calculations. The aerosol vertical distribution is based on a Gaussian distribution function (GDF), as used by [13]. The equation of GDF is as follows:

$$
\begin{gathered}
G D F=\int_{z_{n 2}}^{z_{n 1}} W \frac{e^{-h\left(z-z_{p}\right)}}{\left[1+e^{-h\left(z-z_{p}\right)}\right]^{2}} \\
\eta=\frac{\ln (3+\sqrt{8})}{h}
\end{gathered}
$$


where $W$ is a normalization constant related to total aerosol loading; $z_{n 1}$ and $z_{n 2}$ is aerosol upper limit and lower limit, respectively; $Z_{p}$ is the APH; and $h$ is related to the Half width $\eta$ [10].

In the present study, AOD, APH, and HW range from 0.1 to 0.9 at an interval of 0.2 , from 0 to $2 \mathrm{~km}$ at an interval of $0.5 \mathrm{~km}$, and from 1 to $5 \mathrm{~km}$ at an interval of $1 \mathrm{~km}$, respectively. The upper and lower limits for aerosol height are set as $10 \mathrm{~km}$ and surface level, respectively. Twenty-five aerosol extinction coefficient profiles are used to account for normal aerosol cases, and 100 aerosol extinction coefficient profiles are used to account for dust events. Definitions of Gaussian loading, APH, and HW can be found in [10]. Although most aerosol particles exist near the surface, APH values of up to $2 \mathrm{~km}$ for Asian dust cases are used in accordance with previous investigations [14-17]. As aerosol scattering efficiency is known to influence AMF, five SSA values of 0.99, 0.95, 0.9, 0.85, and 0.8 were adopted. These five SSA values, which are commonly used in northeast Asia [18], were selected as model parameters because the scattering efficiency of aerosols also influence AMF. Figure 3 shows: (a) examples of aerosol extinction profiles under normal conditions with an AOD of 0.5, APH of $0 \mathrm{~km}$, aerosol upper limit of $10 \mathrm{~km}$, and aerosol lower limit of $0 \mathrm{~km}$; and (b) those for an Asian dust case with the same AOD, aerosol upper and lower limits, but with APH of $2 \mathrm{~km}$.
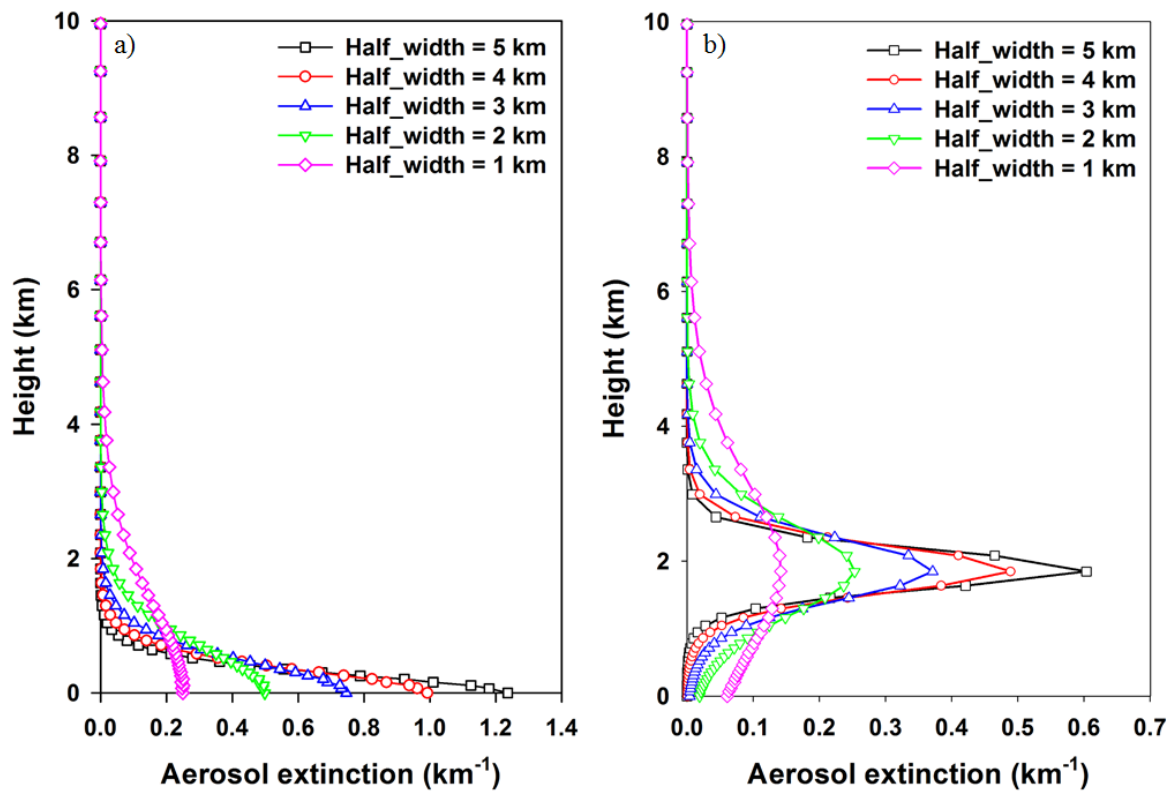

Figure 3. Vertical profiles of the aerosol extinction coefficient with an APH of: (a) $0 \mathrm{~km}$; and (b) $2 \mathrm{~km}$ for various $\mathrm{HW}$.

\subsection{Setting of Aerosol Type}

Because the AMF values for each aerosol type (smoke, dust, and sulfate) have similar patterns with small differences in magnitude, one type (smoke) was chosen for this study. However, we calculated each AMF for various aerosol shapes (spherical and cylinders) using the T-matrix in VLIDORT [19], given the effect of particle shape on the aerosol phase function [20]. Model input values, including fine- and coarse-mode radii and variance, refractive index, and fine-mode fraction for each aerosol type, can be found in [13].

\subsection{Other Settings}

$S Z A$ and $V Z A$ are important model input parameters for AMF because geometric $A M F\left(A_{G} F_{G}\right)$ is calculated as shown in Equation (6). Five $S Z A$ and $V Z A$ values $\left(5^{\circ}, 20^{\circ}, 40^{\circ}, 60^{\circ}\right.$, and $\left.70^{\circ}\right)$ and seven Relative azimuth angle (RAA) values $\left(0^{\circ}, 30^{\circ}, 60^{\circ}, 90^{\circ}, 120^{\circ}, 150^{\circ}\right.$, and $\left.180^{\circ}\right)$ were adopted for 
the present study. $S Z A$ and $V Z A$ values over $70^{\circ}$ were not considered because $\mathrm{NO}_{2} \mathrm{VCD}$ retrieval is difficult in the case of a low signal-to-noise ratio.

$$
\mathrm{AMF}_{G}=\sec S Z A+\sec V Z A
$$

AMF was calculated using surface reflectance from 0.4 to 0.14 , which covers values typical of grassland, ocean, and deciduous forests in the UV-VIS range, because surface reflectance also has a major influence on AMF and varies with surface type.

\section{Results}

\subsection{Influence of $S Z A$ and $V Z A$}

As shown in Figure 4a, SZA and VZA have a strong influence on the variations in $\mathrm{NO}_{2} \mathrm{AMF}$ compared with other parameters because the $\mathrm{AMF}_{\mathrm{G}}$ in Equation (8) increases due to the increased light path between the sun and the satellite via the atmosphere under high-SZA and high-VZA conditions. In general, the pattern of the AMF changes with SZA and VZA in Figure 4 is similar to that in a previous study by [2]. AMF tends to increase when SZA and VZA increase, but decreases in polluted regions when SZA and VZA increase over $60^{\circ}$ when AOD is high. This decreasing trend in $\mathrm{NO}_{2} \mathrm{AMF}$ when SZA and VZA are higher than $60^{\circ}$ at AOD of 0.9 can be ascribed to a reduced path length due to fewer photons surviving Mie scattering to reach the satellite sensor than those at an AOD of 0.1. Figure $4 \mathrm{~b}$ shows the ratio of $\mathrm{AMF}$ and $\mathrm{AMF}_{\mathrm{G}}$ as a function of SZA and VZA at low and high AOD conditions. In this case, the ratio of $\mathrm{AMF}$ and $\mathrm{AMF}_{\mathrm{G}}$ has low value at high SZA and VZA conditions due to the increase in the absorption light path. Figure 4c shows the AMF distribution with respect to AOD and SSA for two different SZA at high- $\mathrm{NO}_{2}$ sites. Figure $4 \mathrm{c}$ shows similar results to those reported for an urban area in a previous study [2]. Notably, an increase in SSA always leads to an increase in AMF, and the rate of increase in AMF as a function of SSA is enhanced for high-AOD conditions, which can be attributed to the increase in the absorption light path. As shown in Figure 4c, for low-SZA conditions at the high- $\mathrm{NO}_{2}$ site, the AMF tends to increase with increasing AOD with an $\mathrm{APH}$ of $0 \mathrm{~km}$, whereas the AMF does not increase with increasing AOD at high SZA. Further details on the effects of SZA on $\mathrm{NO}_{2}$ AMF for various AOD conditions are provided below and in Figure 5.
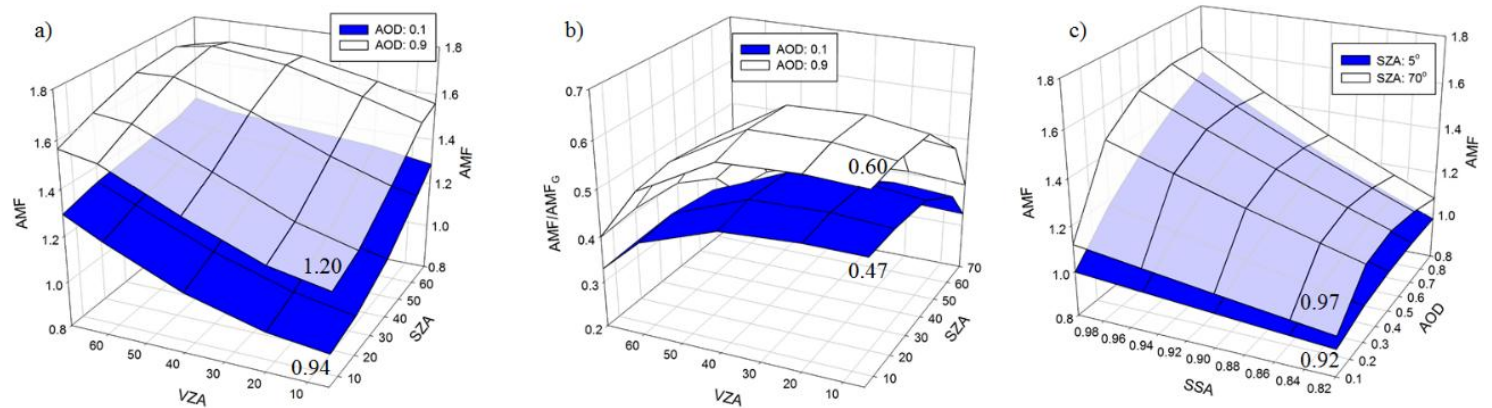

Figure 4. (a) Changes in $\mathrm{NO}_{2}$ AMF at a high- $\mathrm{NO}_{2}$ site as a function of solar zenith angle (SZA) and viewing zenith angle (VZA) at low and high aerosol optical depth (AOD) under conditions of reflectance $=0.05$, relative azimuth angle $(\mathrm{RAA})=50^{\circ}$, wavelength $=441 \mathrm{~nm}$, single scattering albedo $(\mathrm{SSA})=0.95$, aerosol peak height $(\mathrm{APH})=0 \mathrm{~km}$, and half width $(\mathrm{HW})=4 \mathrm{~km}$. (b) Same as Figure 4a, but changes in the ratio of $\mathrm{AMF}$ and (geometric air mass factor) $\mathrm{AMF}_{\mathrm{G}}$. (c) Changes in $\mathrm{NO}_{2} \mathrm{AMF}$ at a high- $\mathrm{NO}_{2}$ site as a function of AOD and SSA at low and high SZAs under conditions of surface reflectance $=0.05, \mathrm{VZA}=47^{\circ}, \mathrm{RAA}=50^{\circ}$, wavelength $=441 \mathrm{~nm}, \mathrm{APH}=0 \mathrm{~km}$, and $\mathrm{HW}=4 \mathrm{~km}$. 


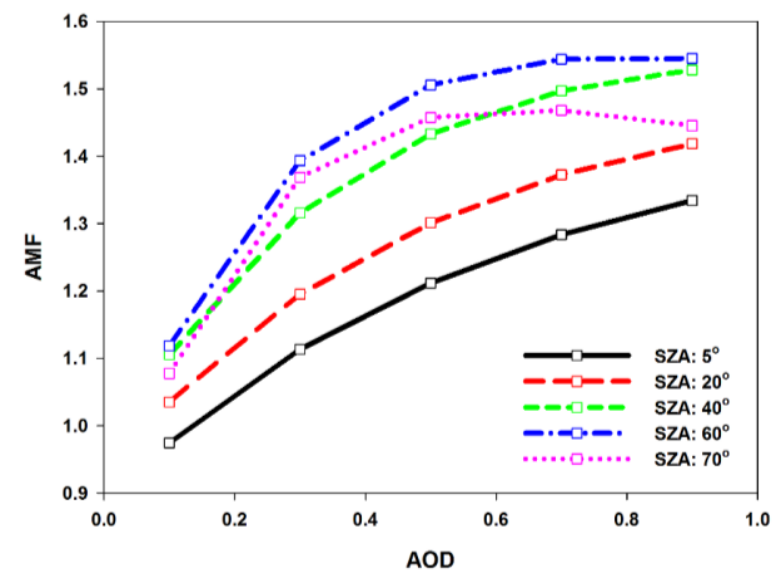

Figure 5. AMF change as a function of SZA and AOD under conditions of surface reflectance $=0.05$, $\mathrm{VZA}=47^{\circ}, \mathrm{RAA}=50^{\circ}$, wavelength $=441 \mathrm{~nm}, \mathrm{APH}=0 \mathrm{~km}, \mathrm{HW}=4 \mathrm{~km}$, and SSA $=0.95$.

Figure 5 shows the variations in AMF caused by changes in SZA and AOD when aerosol is located near the surface (APH $0 \mathrm{~km}$ and $\mathrm{HW} 4 \mathrm{~km}$ ) at the high- $\mathrm{NO}_{2}$ site. AMF increases with increasing AOD at SZA lower than $60^{\circ}$, which implies that the absorption light path tends to increase with increasing aerosol loadings under low-SZA conditions. AMF increases by $37.11 \%$ and $38.40 \%$ at SZA of $5^{\circ}$ and $60^{\circ}$, respectively, when AOD increases from 0.1 to 0.9 . When SZA is $70^{\circ}$, the AMF increases with increasing AODs up to $~ 0.5$. However, the AMF decreases by $2 \%$ (from 1.47 to 1.44) in the AOD range of 0.7 to 0.9. This decreasing trend in AMF may imply a shortened light path due to the lower probability of surviving photons, which are scattered further to reach the detector in the case of high-SZA conditions. Thus, when constructing a $\mathrm{NO}_{2} \mathrm{AMF}$ look-up table, it is helpful to construct the table at fine intervals of SZA and AOD to account for sudden changes in AMF.

\subsection{Influence of Surface Reflectance}

Surface reflectance is an important factor in determining $\mathrm{NO}_{2}$ AMF. Leitão et al. [2] reported that a change in surface reflectance from 0.01 to 0.1 can result in an increase in $\mathrm{NO}_{2}$ AMF by $\sim 90 \%$. According to [21], the minimum Lambertian-equivalent reflectance values at $400 \mathrm{~nm}$ are $0.05,0.06$ and 0.07 for deciduous forests, grassland, and ocean, respectively. However, no previous study has investigated the effects of high surface reflectance under various AOD and SSA conditions on AMF where the Lambertian-equivalent reflectance values are as low as 0.5 and 0.8 , such as on refreezing ice and fresh snow [22]. We compared the effect of high and low surface reflectance values on AMF for various AOD and SSA values, as shown in Figure 6a. The $\mathrm{NO}_{2} \mathrm{AMF}$ tends to increase with increasing surface reflectance at high- $\mathrm{NO}_{2}$ site. The $\mathrm{NO}_{2} \mathrm{AMF}$ for an AOD of 0.1 and SSA of 0.95 increases by $49.6 \%$ (from 1.25 to 1.87 ) at the high- $\mathrm{NO}_{2}$ site when the surface reflectance is 0.04 and 0.14 , respectively. Figure $6 \mathrm{~b}$ shows the variations in $\mathrm{NO}_{2} \mathrm{AMF}$ at high- $\mathrm{NO}_{2}$ site as a function of surface reflectance under various $\mathrm{AOD}$ and SSA conditions. $\mathrm{NO}_{2} \mathrm{AMF}$ increases with increasing surface reflectance between 0.04 and 0.14 . However, the increasing rate in $\mathrm{NO}_{2} \mathrm{AMF}$ as a function of surface reflectance decreases with increasing AOD values due to the increased aerosol shielding effect. In the case of AOD $=0.1$ and $\mathrm{SSA}=0.85$, the $\mathrm{NO}_{2} \mathrm{AMF}$ increases by $38.66 \%$ (from 1.19 to 1.65 ) as surface reflectance changes from 0.04 to 0.14 . In the case of $\mathrm{AOD}=0.9$ and $\mathrm{SSA}=0.85, \mathrm{NO}_{2} \mathrm{AMF}$ increases by $14.08 \%$ (from 1.69 to 1.92 ) when surface reflectance changes from 0.04 to 0.14 . $\mathrm{NO}_{2}$ AMF values under high-SSA conditions are always larger than those in the case of low SSA values, and the influence of SSA is much greater under high-AOD conditions. 

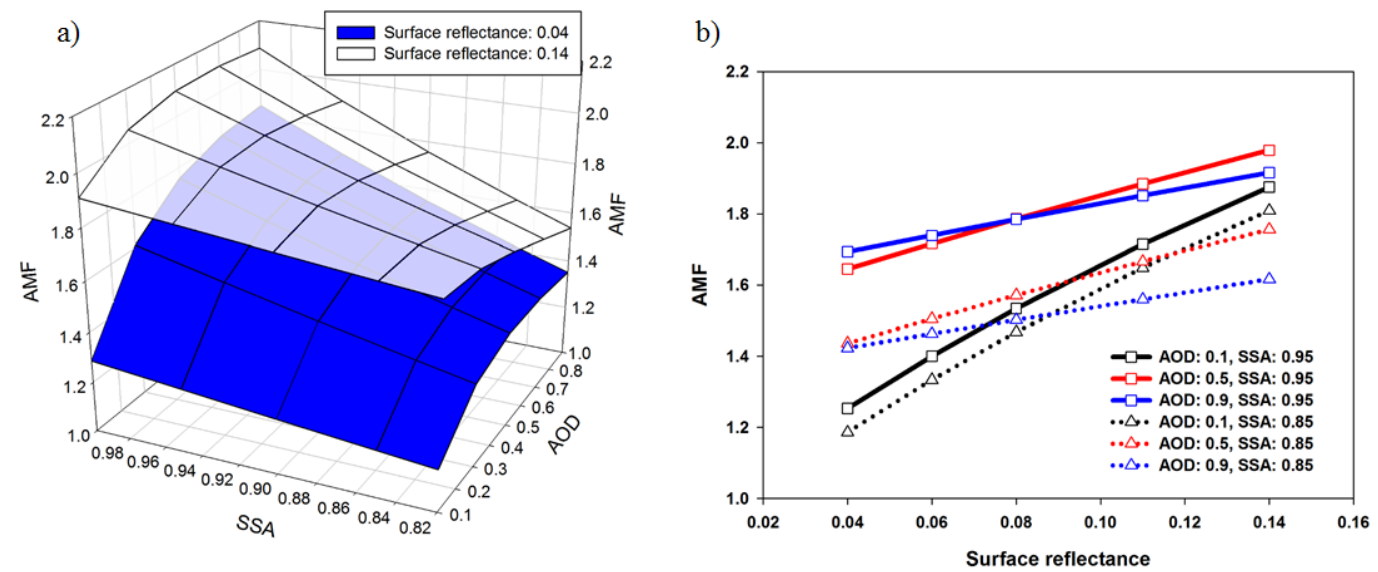

Figure 6. (a) Simultaneous effects of $\mathrm{AOD}, \mathrm{SSA}$, and surface reflectance on $\mathrm{NO}_{2} \mathrm{AMF}\left(\mathrm{SZA}=60^{\circ}\right.$; $\mathrm{VZA}=47^{\circ} ; \mathrm{RAA}=50^{\circ}$; wavelength $=441 \mathrm{~nm} ; \mathrm{APH}=0 \mathrm{~km}$; and $\mathrm{HW}=4 \mathrm{~km}$ ) at the high $-\mathrm{NO}_{2}$ site. (b) AMF change at high- $\mathrm{NO}_{2}$ site as a function of surface reflectance under various AOD and SSA conditions $\left(\mathrm{SZA}=60^{\circ} ; \mathrm{VZA}=47^{\circ} ; \mathrm{RAA}=50^{\circ}\right.$; wavelength $=441 \mathrm{~nm} ; \mathrm{APH}=0 \mathrm{~km}$; and $\left.\mathrm{HW}=4 \mathrm{~km}\right)$.

We compared the effects of low and extremely high surface reflectance values on AMF under several AOD and SSA conditions, as shown in Figure 7. A surface reflectance of 0.8 corresponds to values for after 3-4 days of snowfall. $\mathrm{NO}_{2}$ AMF values at a surface reflectance of 0.8 are much higher than those at a surface reflectance of 0.05 . Furthermore, at a surface reflectance of 0.8 , as AOD increases the AMF decreases despite an APH of $0 \mathrm{~km}$, as the aerosol blocks reflectance from the surface. It is interesting to compare aerosol effects on AMF over low- and high-reflectance areas. Aerosol shielding effects over high-albedo surfaces act to reduce the light path-length on the surface, whereas high-SSA conditions (e.g., SSA $=0.95$ ) lead to an increase in the aerosol albedo effect, which also results in increased AMF over areas with low surface reflectance. Figure 7 shows that $\mathrm{NO}_{2} \mathrm{VCD}$ can be significantly overestimated when using the wrong surface reflectance for AMF calculation over snow surfaces.

a)

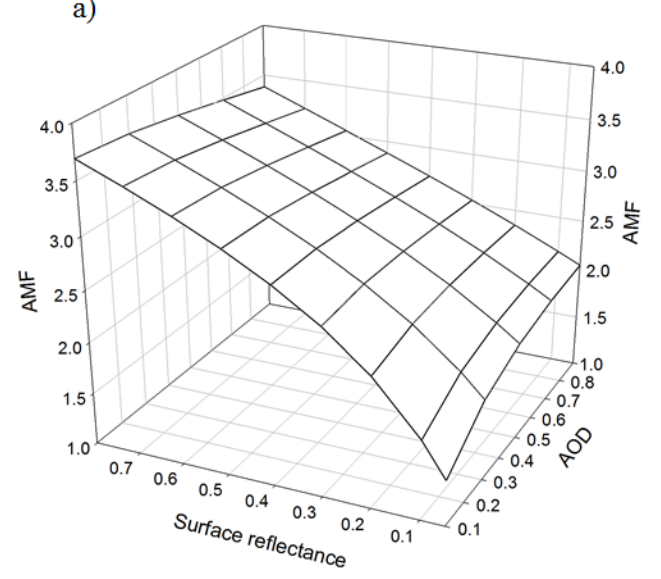

b)

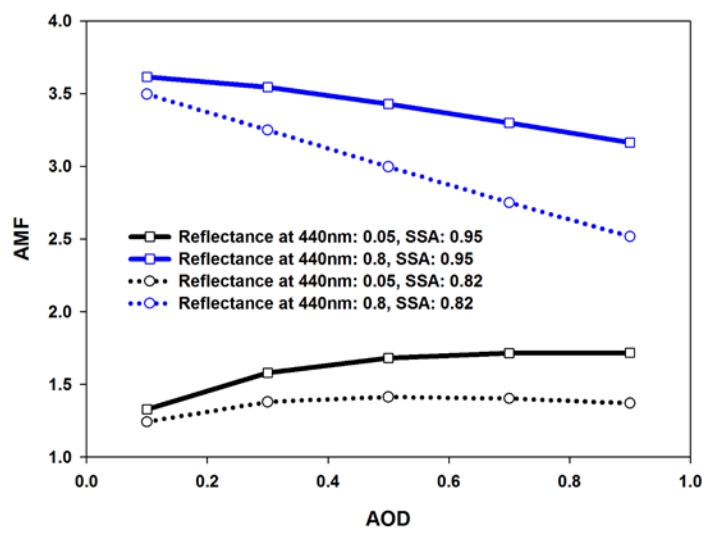

Figure 7. (a) AMF change as a function of $\mathrm{AOD}$ and surface reflectance $\left(\mathrm{SZA}=60^{\circ} ; \mathrm{VZA}=47^{\circ}\right.$; RAA $=50^{\circ}$; wavelength $=441 \mathrm{~nm}$; $\mathrm{APH}=0 \mathrm{~km}$; and $\left.\mathrm{HW}=4 \mathrm{~km}\right)$. (b) AMF change as a function of AOD and SSA for deciduous forest (0.05) and snow surface (0.8) reflectance.

\subsection{Influence of Aerosol Peak Height}

Leitão et al. [2] investigated the effects of AOD, SSA and aerosol extinction profile on $\mathrm{NO}_{2} \mathrm{AMF}$. However, they did not discuss the effect of APH on AMF in detail. The APH effect on $\mathrm{NO}_{2} \mathrm{AMF}$ 
has been studied comprehensively here, as APH may increase or decrease AMF depending on the properties of the aerosol layer. Figure 8a shows the change in $\mathrm{NO}_{2} \mathrm{AMF}$ as a function of $\mathrm{AOD}, \mathrm{APH}$ and $\mathrm{HW}$, which determine the aerosol vertical profile. When APH and $\mathrm{HW}$ are 0 and $5 \mathrm{~km}$, respectively (Figure 3, black squares), the increase in AOD leads to an enhancement in $\mathrm{NO}_{2}$ AMF due to the increased scattering probability within the $\mathrm{NO}_{2}$ layer. Under these conditions of AMF enhancement, AOD changes from 0.1 to 0.9 , which increases AMF by $36 \%$ from 1.36 to 1.85 . The APH increase leads to decreased $\mathrm{NO}_{2} \mathrm{AMF}$, which can be attributed to the shielding effect of the aerosol layer, as shown in Figure $3 \mathrm{~b}$. This shielding relates to the decreased sensitivity below the aerosol layer as more photons are scattered back to the satellite detector before they reach these low altitudes, as described by [2]. Under conditions of $\mathrm{AOD}=0.1$ and $\mathrm{HW}=5 \mathrm{~km}, \mathrm{NO}_{2} \mathrm{AMF}$ decreases by $29 \%$ (from 1.36 to 0.96 ) as APH changes from 0 to $2 \mathrm{~km}$. Under conditions of high AOD (0.9) and a HW of $5 \mathrm{~km}$, the $\mathrm{NO}_{2} \mathrm{AMF}^{\mathrm{A}}$ decreases by $241 \%$ (from 1.85 to 0.54 ) as APH changes from 0 to $2 \mathrm{~km}$. Therefore, the APH effect on $\mathrm{NO}_{2} \mathrm{AMF}$ is greater in the case of high-AOD conditions. However, as shown in Figure $8 \mathrm{a}, \mathrm{NO}_{2}$ AMF shows a smaller variation as a function of APH under low HW conditions (e.g., $\mathrm{HW}=1 \mathrm{~km}$ (Figure 3, purple diamonds) compared with $\mathrm{HW}=5 \mathrm{~km}$ (Figure 3, black squares)), as neither shielding nor albedo has a large effect on $\mathrm{NO}_{2}$ AMF. We found that the increase in AOD leads to an increase in $\mathrm{NO}_{2}$ AMF under low-APH conditions $(0$ and $0.5 \mathrm{~km})$ due to the increased albedo effect of the aerosol layer. However, as shown in Figure 8b, as the increase in APH enhances the shielding effect of the aerosol layer, the $\mathrm{NO}_{2}$ AMF decreases with increasing AOD above $1 \mathrm{~km}$ of APH. Figure 8c shows the change in $\mathrm{NO}_{2} \mathrm{AMF}$ as a function of $\mathrm{AOD}, \mathrm{APH}$, and $\mathrm{SZA}$ at the high- $\mathrm{NO}_{2}$ site, and Figure $8 \mathrm{~d}$ shows the change in $\mathrm{NO}_{2} \mathrm{AMF}$ as a function of SZA and $\mathrm{APH}$ at AOD $=0.3$. The increase in AOD leads to increases in $\mathrm{NO}_{2}$ AMF under low-APH conditions ( $\mathrm{APH}=0$ and $0.5 \mathrm{~km}$ ) but to decreases in $\mathrm{NO}_{2}$ AMF under high-APH conditions $(\mathrm{APH}=1.5$ and $2 \mathrm{~km})$, which implies that the shielding effect is enhanced with increased SZA at high APH. We examined the AMF sensitivity to simple rectangular aerosol distributions that reflect polluted environments where convection creates very homogeneous vertical aerosol distribution within the planter boundary layer. Figure 8e shows the change in $\mathrm{NO}_{2}$ AMF as functions of AOD, surface reflectance, and aerosol upper limit. $\mathrm{NO}_{2} \mathrm{AMFs}$ are lower with aerosol upper limit of $5 \mathrm{~km}$ than those with aerosol upper limit of $1 \mathrm{~km}$ due to the aerosol shielding effect especially in high AOD conditions.

We additionally examined the APH effect on AMF under various AOD and SSA conditions. Figure 9a shows the $\mathrm{NO}_{2}$ AMF variation due to changes in SSA, APH, and HW at AOD = 0.5; the effects of AOD, SSA, and APH on $\mathrm{NO}_{2}$ AMF are shown in Figure 9b. $\mathrm{NO}_{2}$ AMF decreases with decreasing SSA since the absorbing aerosol contributes to a decreased light path. When SSA changes from 0.99 to 0.82 , and $\mathrm{APH}=0 \mathrm{~km}$ and $\mathrm{HW}=5 \mathrm{~km}$, the $\mathrm{NO}_{2} \mathrm{AMF}$ decreases by $21.05 \%$ (from 1.90 to 1.50) in cases of $\mathrm{APH}=0 \mathrm{~km}$, but for $\mathrm{HW}=1 \mathrm{~km}$ the AMF decreases only by $17.86 \%$ (from 1.12 to 0.92 ). The decrease in $\mathrm{NO}_{2} \mathrm{AMF}$ is greater at high $\mathrm{HW}$ than at low $\mathrm{HW}$, which implies an enhancement of the shielding effect of the aerosol layer due to high HW. The AMF is reduced by $12.1 \%$ (from 0.57 to 0.50 ) when SSA is changed from 0.99 to 0.82 under conditions of AOD $=0.9$ and $\mathrm{APH}=2 \mathrm{~km}$. Under the same AOD and SSA conditions, but with APH $=0 \mathrm{~km}$, the AMF is reduced by $26.8 \%$ (from 1.87 to 1.37), which shows the higher sensitivity of AMF to the changes in SSA under low-APH conditions. 


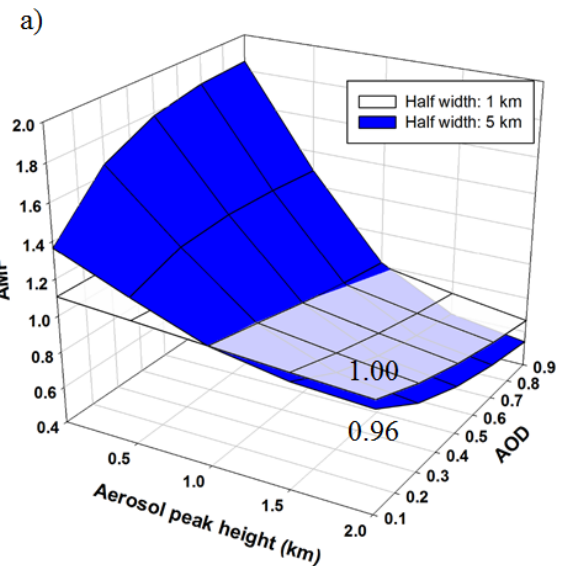

b)
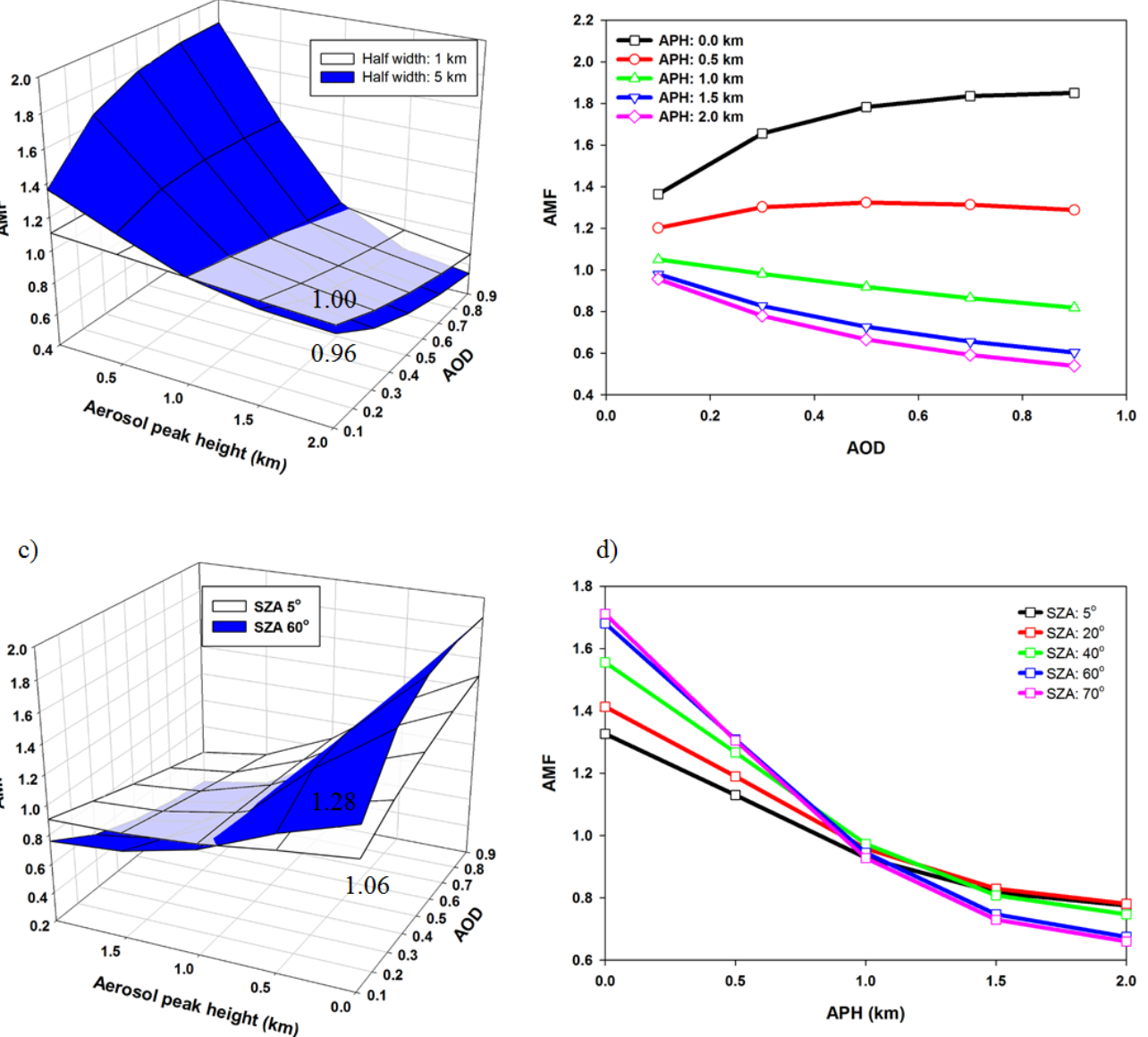

d)

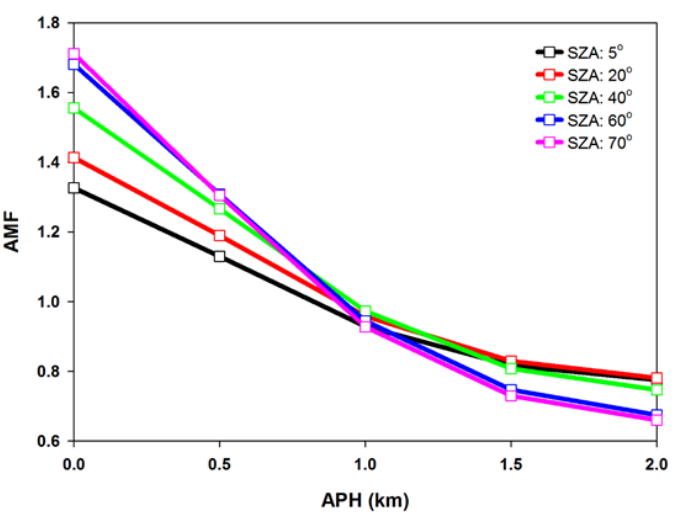

e)
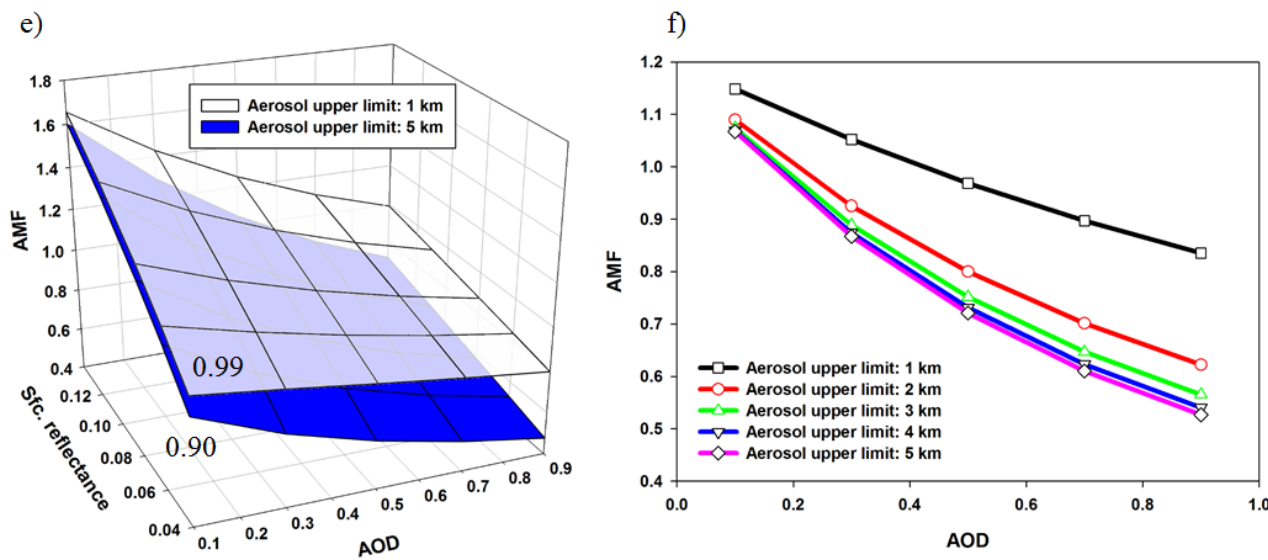

Figure 8. (a) AMF change as a function of AOD, APH, and HW; (b) AMF change as a function of AOD and APH; (c) AMF change as a function of AOD, APH, and SZA at HW $5 \mathrm{~km}$; and (d) AMF change as a function of $\mathrm{APH}$ and $\mathrm{SZA}$ at $\mathrm{HW} 5 \mathrm{~km}\left(\mathrm{SZA}=60^{\circ} ; \mathrm{VZA}=47^{\circ} ; \mathrm{RAA}=50^{\circ} ; \mathrm{SSA}=0.95\right.$; and surface reflectance $=0.05)$; (e) AMF change as a function of AOD, surface reflectance and aerosol upper limit under rectangular distribution cases of aerosol; and (f) AMF change as a function of AOD and aerosol upper limit. 

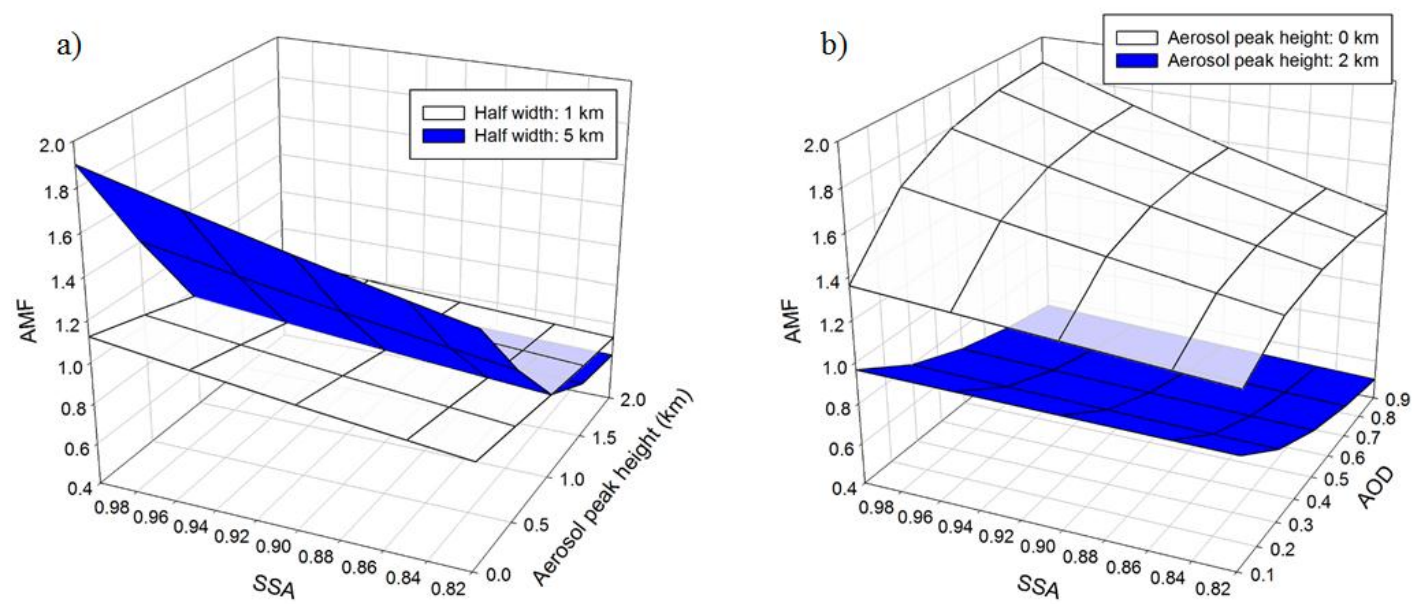

Figure 9. (a) $\mathrm{NO}_{2} \mathrm{AMF}$ as a function of $\mathrm{SSA}, \mathrm{APH}$, and $\mathrm{HW}\left(\mathrm{SZA}=60^{\circ} ; \mathrm{VZA}=47^{\circ} ; \mathrm{RAA}=50^{\circ}\right.$; wavelength $=441 \mathrm{~nm}$; reflectance $=0.05$; and $\mathrm{AOD}=0.5) .(\mathbf{b}) \mathrm{NO}_{2} \mathrm{AMF}$ as a function of $\mathrm{AOD}, \mathrm{SSA}$, and $\mathrm{APH}\left(\mathrm{SZA}=60^{\circ} ; \mathrm{VZA}=47^{\circ} ; \mathrm{RAA}=50^{\circ} ;\right.$ wavelength $=441 \mathrm{~nm}$; reflectance $=0.05 ;$ and $\left.\mathrm{HW}=5 \mathrm{~km}\right)$.

\subsection{Diurnal Effects of $\mathrm{NO}_{2}$ Profile}

$\mathrm{NO}_{2}$ concentrations in the planetary boundary layer show a diurnal variation, especially over fossil fuel source regions [1]; consequently, tropospheric $\mathrm{NO}_{2}$ VCD obtained from OMI (overpass time: 13:30 local time) are generally different from those obtained from SCHIMACHY or GOME-2 (10:00 and 09:30 local time, respectively) on the same day due to differences in both $\mathrm{NO}_{2} \mathrm{SCD}$ and AMF [23]. The $\mathrm{NO}_{2}$ AMF at noon generally shows an increase due to the change in $\mathrm{NO}_{2}$ shape factor with the increase in mixing layer height. To investigate the change in AMF with diurnal variations in the $\mathrm{NO}_{2}$ profile, $\mathrm{NO}_{2}$ AMF was calculated using three $\mathrm{NO}_{2}$ profiles obtained from the Goddard Earth Observing System-Chem Model (GEOS-Chem; [24]) for December 2006 at the peak times of $\mathrm{NO}_{2}$ concentration (0700 LT and 2000 LT) and at noon (1300 LT) in Beijing. A detailed description of this approach, including the emission inventory used for the GEOS-Chem modeling, can be found in a previous study [25].

Figure 10 shows the normalized $\mathrm{NO}_{2}$ shape factor for 0700,1300 , and $2000 \mathrm{LT}$, and the absolute percent difference error of calculated AMF using $\mathrm{NO}_{2}$ profiles between 1300 and $0700 \mathrm{LT}$ (white) and between 0700 and $2000 \mathrm{LT}$ (blue). The AMF calculated using the $\mathrm{NO}_{2}$ profile at $0700 \mathrm{LT}$ is similar to that at $2000 \mathrm{LT}$ (percent difference $<15 \%$ ) due to a similar normalized $\mathrm{NO}_{2}$ shape factor, whereas the AMF at 1300 LT shows a significant difference (percent difference $>63 \%$ ) in AMF to that at 0700 LT (and $2000 \mathrm{LT}$ ) due to a normalized $\mathrm{NO}_{2}$ shape factor as well as a mixing layer height that is significantly different. Of note, the AMF changes are large under high-AOD and high-APH conditions as the $\mathrm{NO}_{2}$ profile changes diurnally. Therefore, in order to improve AMF calculation accuracy in geostationary satellite measurements such as GEMS, TEMPO, and Sentinel-4, it is important to account for the diurnal variation in $\mathrm{NO}_{2}$ profiles, especially over high- $\mathrm{NO}_{2}$ sites such as industrial regions, power plants, and megacities. 
a)

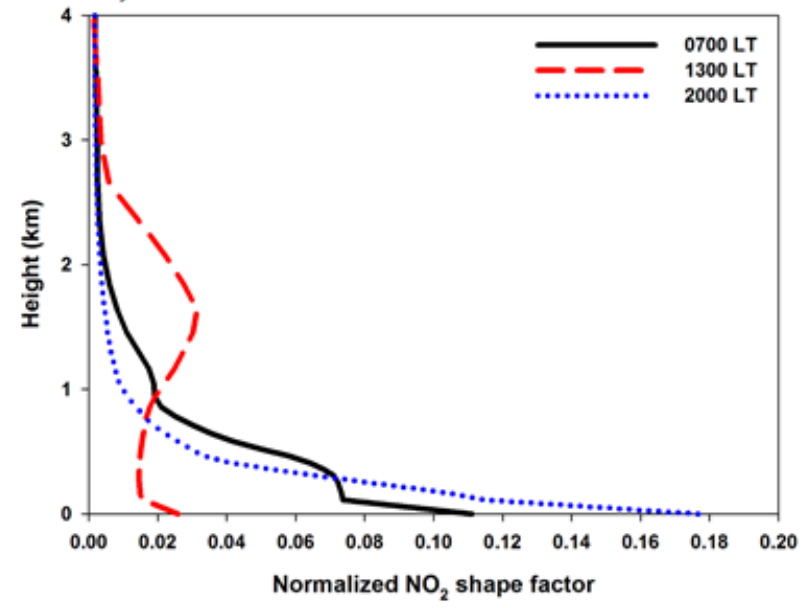

b)

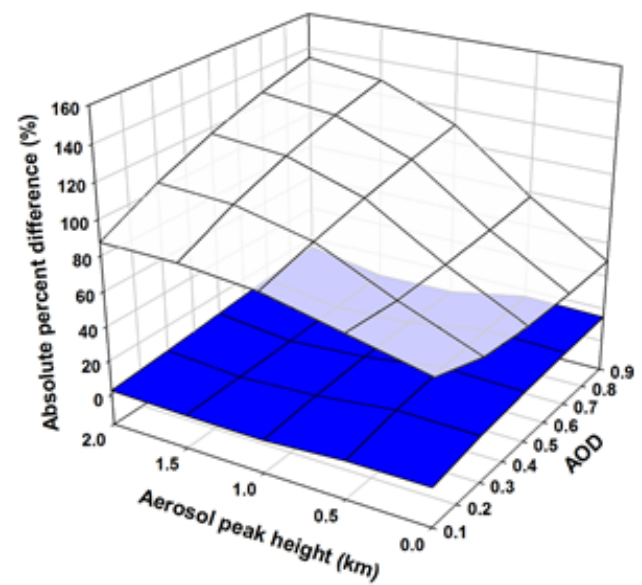

Figure 10. (a) Normalized $\mathrm{NO}_{2}$ shape factor at 0700, 1300, and $2000 \mathrm{LT}$ (local time); and (b) absolute percent difference error of calculated AMF using $\mathrm{NO}_{2}$ profiles between 1300 and 0700 LT (white) and between 0700 and $2000 \mathrm{LT}$ (blue) $\left(\mathrm{SZA}=60^{\circ} ; \mathrm{VZA}=40^{\circ} ; \mathrm{RAA}=50^{\circ}\right.$; wavelength $=441 \mathrm{~nm}$; reflectance $=0.05 ; \mathrm{SSA}=0.95 ;$ and $\mathrm{HW}=4 \mathrm{~km})$.

\subsection{Influence of Aerosol Shape}

To investigate the effect of aerosol shape on AMF, we calculated AMF for two types of aerosol shape (spherical and cylindrical) as a function of APH and RAA (Figure 11a), and as a function of APH and AOD (Figure 11b). Large AMF values are found for both spherical and cylindrical aerosol shapes at RAA of $0^{\circ}$ and an APH of $0 \mathrm{~km}$, whereas AMF has the smallest value at RAA of $160^{\circ}$ due to a back-scattering phase function that is smaller than that in the forward direction [26]. The AMF difference between spheres and cylinders is $\sim 14 \%$ at an APH of $0 \mathrm{~km}$ and RAA of $0^{\circ}$, is smaller under low-APH conditions, and becomes large at high AOD. For both spherical and cylindrical aerosols, the change in APH from 0 to $2 \mathrm{~km}$ leads to a significant change in AMF (spherical: $180 \%$; cylindrical: $\sim 130 \%$ ), especially under high-AOD and low-RAA conditions. The aerosol shape is also found to have a noticeable effect on AMF under high-AOD and small-RAA conditions.
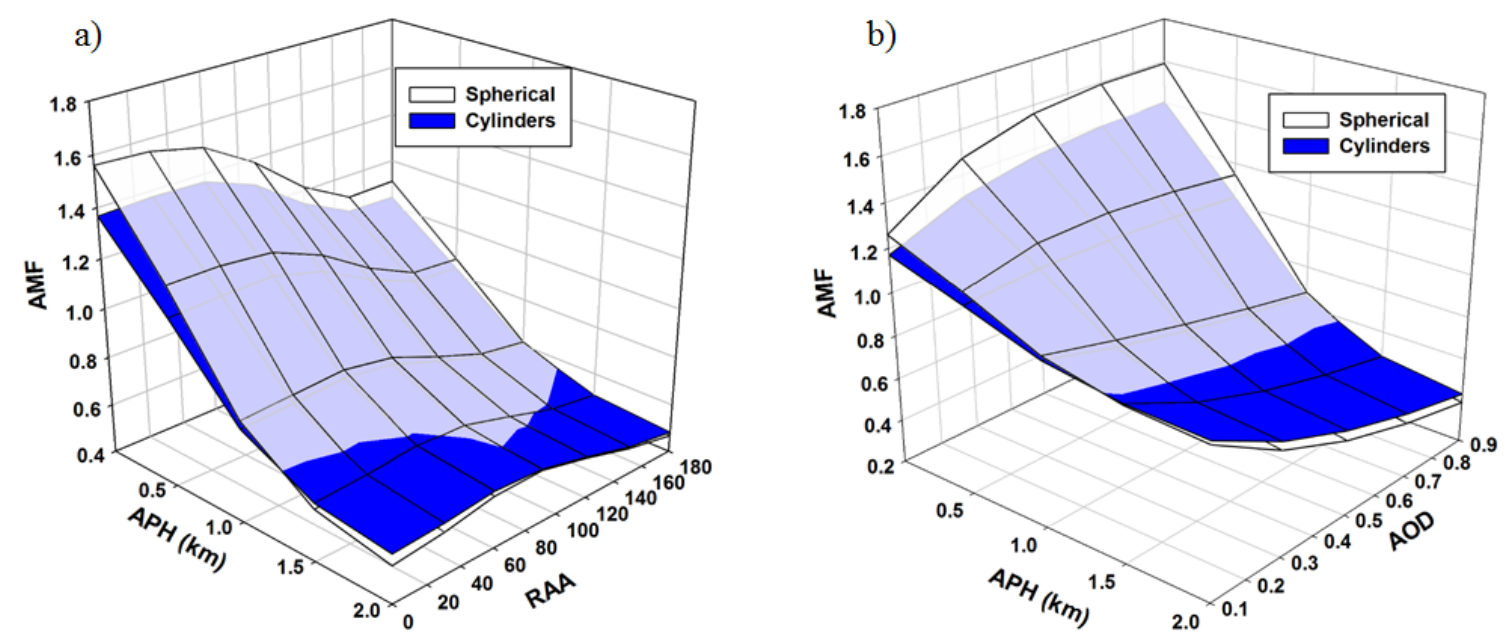

Figure 11. (a) $\mathrm{NO}_{2} \mathrm{AMF}$ as a function of $\mathrm{AOD}, \mathrm{RAA}$, and $\mathrm{APH}\left(\mathrm{AOD}=0.5 ; \mathrm{SZA}=60^{\circ} ; \mathrm{VZA}=47^{\circ}\right.$; $\mathrm{RAA}=50^{\circ}$; wavelength $=441 \mathrm{~nm}$; reflectance $=0.05$; and $\left.\mathrm{HW}=4 \mathrm{~km}\right)$; and $(\mathrm{b}) \mathrm{NO}_{2} \mathrm{AMF}$ as a function of $\mathrm{AOD}, \mathrm{APH}$, and two types of aerosol shape $\left(\mathrm{SZA}=60^{\circ} ; \mathrm{VZA}=47^{\circ}\right.$; wavelength $=441 \mathrm{~nm}$; reflectance $=0.05 ; \mathrm{RAA}=0^{\circ} ; \mathrm{HW}=4 \mathrm{~km}$; and SSA $\left.=0.85\right)$. 


\subsection{Estimation of $\mathrm{NO}_{2}$ AMF Errors}

As discussed above, the accuracy of the input data for the RTM calculations (e.g., AOD, SSA, and $\mathrm{APH}$ ) affects the AMF accuracy. Therefore, we quantified the AMF errors due to uncertainty in the input data. The AMF errors in this study are presented as the percent difference of AMF compared with the true AMF. Thus, aerosol data $(\mathrm{AOD}=0.40$; and SSA $=0.88$ ) were averaged from Aerosol Robotic Network (AERONET) measurements in December 2011 in Beijing and used as the true aerosol data for the AMF calculations. An APH of $0 \mathrm{~km}$ was assumed as a true value for the AMF calculation. To calculate the AMF, the various input parameter values were set as follows. The range of SZA was set between $30^{\circ}$ and $70^{\circ}$, which covers the typical SZA in Beijing. The range of AOD was set from 0.28 to 0.52 at an interval of 0.06 , because the AOD retrieved in the near-UV wavelength of the OMI has a $\pm 30 \%$ error compared with the AERONET AOD [27]. The range of SSA was set from 0.84 to 0.92 at an interval of 0.02 , as the SSA retrieved by the OMI/Aura level-2 near-UV two-channel algorithm (OMAERUV) has a \pm 0.04 error compared with the AERONET SSA [18]. To calculate AMF, the $\mathrm{NO}_{2}$ profile shown in Figure 2a is used as the input for the RTM calculations.

Figure 12a shows the percent difference in AMF calculated with various AOD and SSA values against the true AMF. As mentioned above, the true AMF values are obtained with AOD $=0.4$ and $\mathrm{SSA}=0.88$, which are obtained by averaging AERONET data in Beijing for December 2011. The true AMF values are 1.64 and 0.79 in Figure 12a,b, respectively. In Figure 12a, where APH is $0 \mathrm{~km}$ and where AOD is 0.52 , which is $30 \%$ smaller than the true $\mathrm{AOD}(0.4)$, the $\mathrm{NO}_{2} \mathrm{AMF}$ value is underestimated by $3.67 \%$ compared with the true AMF (1.64). However, when AOD is 0.28 , which is $30 \%$ smaller than the true AOD, the $\mathrm{NO}_{2}$ AMF value is overestimated by $4.85 \%$. When SSA is 0.84 , which is smaller than the true SSA of 0.88 , the $\mathrm{NO}_{2}$ AMF value is overestimated by $4.46 \%$ compared with the true AMF. However, when SSA is 0.92 , the $\mathrm{NO}_{2} \mathrm{AMF}$ value is underestimated by $4.77 \%$. As shown in Figure $12 \mathrm{~b}$ where $\mathrm{APH}$ is $3 \mathrm{~km}$, when using an AOD value that is $30 \%$ higher than the true AOD value, the $\mathrm{NO}_{2}$ $\mathrm{AMF}$ is overestimated by $8.35 \%$ compared with the true AMF value (0.79). However, In Figure 12b, when using an AOD value that is $30 \%$ lower than true AOD value, the $\mathrm{NO}_{2} \mathrm{AMF}$ is underestimated by $9.53 \%$. We found the effects of SSA on $\mathrm{NO}_{2} \mathrm{AMF}$ to be negligible for the case of high $\mathrm{APH}(3 \mathrm{~km})$, as $\mathrm{NO}_{2}$ AMF is overestimated by only $0.90 \%$ and underestimated by $0.93 \%$ when using SSA values of 0.84 and 0.92 , respectively. The accuracy of AOD and SSA has an effect on the accuracy of $\mathrm{NO}_{2} \mathrm{AMF}$ when APH is $0 \mathrm{~km}$. Under high-APH conditions $(0.3 \mathrm{~km})$, however, AOD is predicted to have more of an impact on AMF accuracy than is SSA.
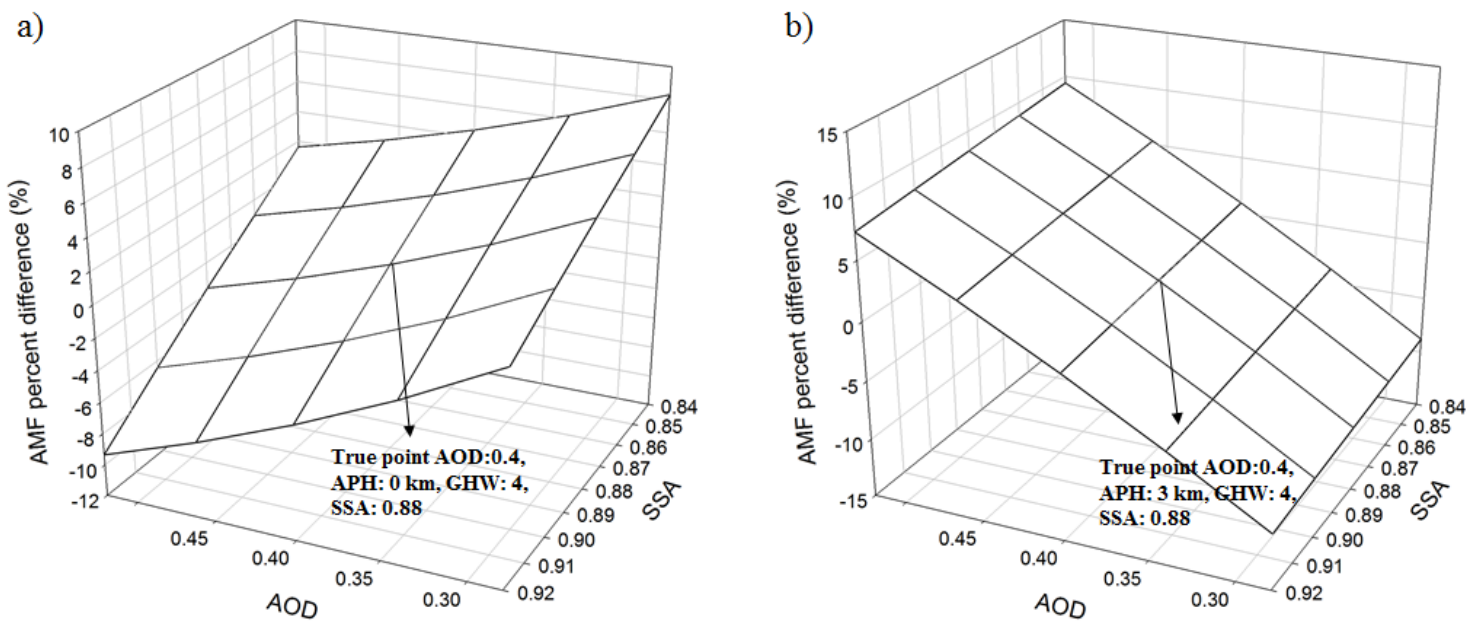

Figure 12. (a) Percent difference in AMF calculated with various AOD and SSA values compared with the true AMF calculated with $\mathrm{AOD}=0.4$ and $\mathrm{SSA}=0.88$ under conditions of $\mathrm{APH}=0 \mathrm{~km}$ and $\mathrm{HW}=4 \mathrm{~km}$; and (b) those under the same conditions but for $\mathrm{APH}=3 \mathrm{~km}$. 
As shown in Figure 13, we found that errors in APH information cause significant errors in the $\mathrm{NO}_{2} \mathrm{AMF}$ calculation. Under the condition of $\mathrm{SZA}=70^{\circ}, \mathrm{AOD}=0.4$, and $\mathrm{SSA}=0.8$, an $\mathrm{APH}$ error of $2 \mathrm{~km}$ causes and error in AMF of $\sim 70 \%$. The magnitude of the error in the AMF calculations due to inaccurate APH information becomes larger with increasing SZA. If the wrong APH value is used for AMF calculations under high-SZA conditions (e.g., winter season, early morning, or late afternoon), significant errors in AMF as well as $\mathrm{NO}_{2} \mathrm{VCD}$ would be expected. AMF calculations may be particularly susceptible to errors associated with inaccurate APH information during long-range transported dust events when the APH is usually higher and/or aerosol vertical profiles are difficult to predict.

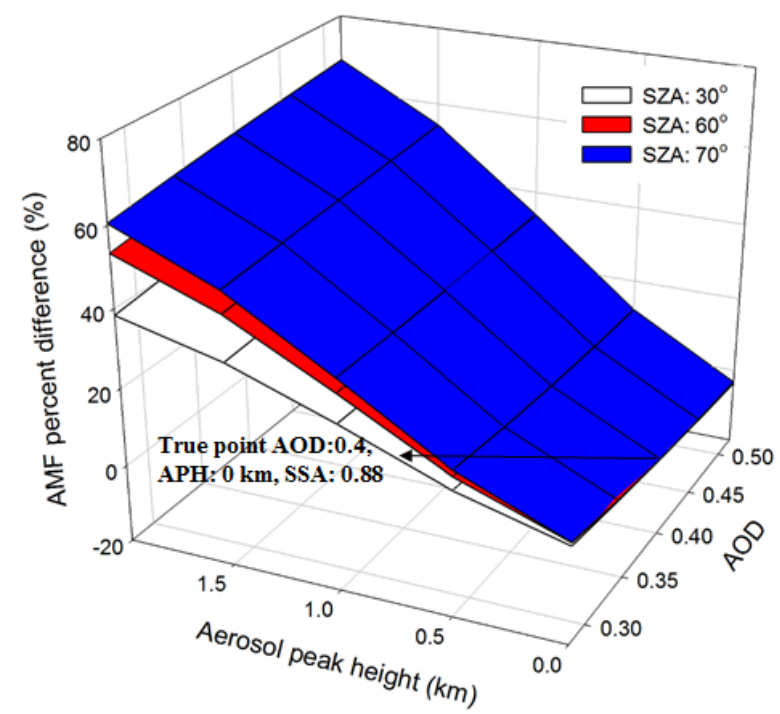

Figure 13. Percent difference in AMF calculated with various APH, AOD, and SZA values compared with the true $\mathrm{AMF}$ calculated with $\mathrm{APH}=0 \mathrm{~km}, \mathrm{AOD}=0.4$, and various $\mathrm{SZA}\left(30^{\circ}, 60^{\circ}\right.$, and $\left.70^{\circ}\right)$ with $\mathrm{SSA}=0.88$ and $\mathrm{HW}=5 \mathrm{~km}$.

\section{Discussion}

The accuracy of $\mathrm{NO}_{2}$ AMF is a key factor to retrieve $\mathrm{NO}_{2} \mathrm{VCD}$ from satellite measurement $[2,7]$. Several previous studies reported the $\mathrm{NO}_{2} \mathrm{AMF}$ error arising from uncertainties in RTM input parameters $[5,28]$. Leitao et al. [2] carried out a $\mathrm{NO}_{2} \mathrm{AMF}$ sensitivity study under various conditions such as aerosol vertical profiles, SSA, surface reflectance, and so on.

- The AMF variations due to the change in aerosol properties in low surface reflectance shows agreements with those reported in the previous study [2]. However, we, for the first time, found that at high surface reflectance conditions such as snowy surface, AMF decreases as AOD increases despite on $\mathrm{APH}$ of $0 \mathrm{~km}$ due to the aerosol shielding effect on the reflected radiance (Figure 7).

- $\quad$ Leitão et al. [2] discussed the effects of $\mathrm{APH}$ on $\mathrm{NO}_{2} \mathrm{AMF}$ using several observed aerosol vertical profiles. It reported that aerosol profile, SSA and AOD contributes to the $\mathrm{NO}_{2} \mathrm{AMF}$. However, we comprehensively examined the AMF variation using 125 aerosol vertical profile types simultaneously under various AOD, SSA, and aerosol shape and geometry conditions. Our study found that an increase in AOD at high altitude induces the decrease in $\mathrm{NO}_{2}$ AMF due to aerosol shielding effect while the enhanced AOD at low altitude leads to the increased AMF due to aerosol albedo effect. Under conditions of high AOD (0.9) and a $\mathrm{HW}$ of $5 \mathrm{~km}$, the $\mathrm{NO}_{2} \mathrm{AMF}$ decreases by $241 \%$ (from 1.85 to 0.54 ) as $\mathrm{APH}$ changes from 0 to $2 \mathrm{~km}$ at high- $\mathrm{NO}_{2}$ site such as Beijing (Figure 8). 
- We also investigated the effect of diurnal variation in the $\mathrm{NO}_{2}$ profile on $\mathrm{NO}_{2} \mathrm{AMF}$, for future geostationary satellite measurements. The $\mathrm{NO}_{2} \mathrm{AMF}$ at $1300 \mathrm{LT}$ shows a significant difference (percent difference $>63 \%$ ) from that at $0700 \mathrm{LT}$ due to the difference of $\mathrm{NO}_{2}$ shape factors at high- $\mathrm{NO}_{2}$ site (Figure 10).

- Lastly, we investigated the effect of aerosol shape on AMF, The AMF difference between spherical and non-spherical aerosol shape becomes large at the conditions of high AOD, low APH and RAA of $0^{\circ}$ (Figure 11).

In this present study, we simultaneously investigated the effects of aerosol properties (AOD, SSA, $\mathrm{APH}, \mathrm{HW}$ and aerosol shape), geometry information (SZA, VZA and RAA), surface reflectance and $\mathrm{NO}_{2}$ vertical profile on $\mathrm{NO}_{2}$ AMF. The results found in this present study show that it is important to use accurate aerosol extinction profiles and surface reflectance information along with other aerosol information under high- $\mathrm{NO}_{2}$ conditions when constructing a $\mathrm{NO}_{2}$ AMF look-up table or calculate $\mathrm{NO}_{2}$ AMF in DOAS retrieval. In addition, it is important to account for the diurnal variation in $\mathrm{NO}_{2}$ profiles for the geostationary satellite measurements especially over high- $\mathrm{NO}_{2}$ sites such as industrial regions, power plants, and megacities.

In current $\mathrm{NO}_{2}$ retrieval algorithms adopted for space-borne measurements, the aerosol information such as aerosol extinction profile and SSA are mostly obtained from chemical transfer model $[6,23,29]$. Especially, the aerosol vertical distribution information can be obtained from the high spectral resolution data of Oxygen A band from either Greenhouse Gases Observing Satellite (GOSAT) or Orbiting Carbon Observatory 2 (OCO-2). Furthermore, TROPOspheric Monitoring Instrument (TROPOMI), which will be launched in 2017, is planned to provide the aerosol layer height information using Oxygen A band. Such aerosol layer height information is expected to be helpful for an improvement on $\mathrm{NO}_{2}$ AMF accuracy.

This study was conducted for the clear sky conditions. In the future, however, the sensitivity studies need to be carried out under cloud condition, since satellite measurements are frequently affected by cloud.

\section{Summary and Conclusions}

AMF errors are much larger than the spectral fitting errors generally induced for $\mathrm{NO}_{2} \mathrm{VCD}$ retrieval in the DOAS $\mathrm{NO}_{2}$ algorithm. In this study, we examined the simultaneous effects of APH, various aerosol properties, and geometric information on AMF at sites with high concentrations of $\mathrm{NO}_{2}$. Both geometric information and aerosol properties are important in calculating AMF at the high- $\mathrm{NO}_{2}$ site. Over snowy surfaces (surface reflectance $=0.8$ ), increases in AOD lead to AMF decreases, which is the opposite of the trend for surfaces without snow where increases in AOD lead to increased AMF.

When the APH is in the boundary layer where most $\mathrm{NO}_{2}$ exists, an increase in AOD leads to an increase in AMF, whereas when the APH is high above the boundary layer, AMF decreases due to the shielding effects of aerosols. HW is also an important parameter in determining AMF. When estimating the effects of aerosol input data error on AMF calculations, AOD and SSA errors play a large role at low APH $(\mathrm{APH}=0 \mathrm{~km})$; however, we found that errors in SSA are negligible at high APH $(\mathrm{APH}=3 \mathrm{~km})$. We also found that inaccurate $\mathrm{APH}$ information causes significant errors in $\mathrm{NO}_{2} \mathrm{AMF}$ calculations. The aerosol shape is found to have an effect on AMF, especially under high-AOD and small-RAA conditions.

Acknowledgments: This research was supported by the GEMS program of the Ministry of Environment, Korea and the Eco Innovation Program of KEITI (2012000160002).

Author Contributions: Data collection and treatment were done by Ukkyo Jeoung and Daesung Lee. Data analysis of DOAS method was conducted by Hyunkee Hong, Hanlim Lee, Jhoon Kim and Jaeyong Ryu.

Conflicts of Interest: The authors declare no conflict of interest. 


\section{References}

1. Boersma, K.F.; Jacob, D.J.; Trainic, M.; Rudich, Y.; DeSmedt, I.; Dirksen, R.; Eskes, H.J. Validation of urban $\mathrm{NO}_{2}$ concentrations and their diurnal and seasonal variations observed from the SCIAMACHY and OMI sensors using in situ surface measurements in Israeli cities. Atmo. Chem. Phys. 2009, 9, 3867-3879. [CrossRef]

2. Leitão, J.; Richter, A.; Vrekoussis, M.; Kokhanovsky, A.; Zhang, Q.J.; Beekmann, M.; Burrows, J.P. On the improvement of $\mathrm{NO}_{2}$ satellite retrievals-aerosol impact on the airmass factors. Atmo. Meas. Tech. 2010, 3, 475-493. [CrossRef]

3. Lin, J.T. Satellite constraint for emissions of nitrogen oxides from anthropogenic, lightning and soil sources over East China on a high-resolution grid. Atmo. Chem. Phys. 2012, 12, 2881-2898. [CrossRef]

4. Zoogman, P.; Liu, X.; Suleiman, R.; Pennington, W.; Flittner, D.; Al-Saadi, J.; Hilton, B.; Nicks, D.; Newchurch, M.; Carr, J. Tropospheric emissions: Monitoring of pollution (tempo). J. Quant. Spectrosc. Radiat. Transf. 2017, 186, 17-39. [CrossRef]

5. Boersma, K.F.; Bucsela, E.; Brinksma, E.J.; Gleason, J.F. $\mathrm{NO}_{2}$ OMI Algorithm Theoretical Basis Document; Distributed Active Archive Centers: Greenbelt, MD, USA, 2002; Volume 4, pp. 13-36.

6. Valks, P.; Pinardi, G.; Richter, A.; Lambert, J.C.; Hao, N.; Loyola, D.; van Roozendael, M.; Emmadi, S. Operational total and tropospheric $\mathrm{NO}_{2}$ column retrieval for GOME-2. Atmos. Meas. Tech. Discuss. 2011, 4, 1617-1676. [CrossRef]

7. Boersma, K.F.; Eskes, H.J.; Brinksma, E.J. Error analysis for tropospheric $\mathrm{NO}_{2}$ retrieval from space. J. Geophys. Res. Atmos. 2004, 109. [CrossRef]

8. Stutz, J.; Platt, U. Numerical analysis and estimation of the statistical error of differential optical absorption spectroscopy measurements with least-squares methods. Appl. Opt. 1996, 35, 6041-6053. [CrossRef] [PubMed]

9. Palmer, P.I.; Jacob, D.J.; Chance, K.V.; Martin, R.V.; Spurr, R.J.; Kurosu, T.; Bey, I.; Yantosca, R.M.; Fiore, A.; Li, Q. Air mass factor formulation for spectroscopic measurements from satellites: Application to formaldehyde retrievals from the Global Ozone Monitoring Experiment. J. Geophys. Res. Atmos. 2001, 106, 14539-14550. [CrossRef]

10. Spurr, R.; Christi, M. On the generation of atmospheric property Jacobians from the (V) LIDORT linearized radiative transfer models. J. Quant. Spectrosc. Radiat. Transf. 2014, 142, 109-115. [CrossRef]

11. Emmons, L.K.; Walters, S.; Hess, P.G.; Lamarque, J.F.; Pfister, G.G.; Fillmore, D.; Granier, C.; Guenther, A.; Kinnison, D.; Laepple, T.; et al. Description and evaluation of the Model for Ozone and Related chemical Tracers, version 4 (MOZART-4). Geosci Model. Dev. 2010, 3, 43-67. [CrossRef]

12. Dirksen, R.J.; Boersma, K.F.; Eskes, H.J.; Ionov, D.V.; Bucsela, E.J.; Levelt, P.F.; Kelder, H.M. Evaluation of stratospheric $\mathrm{NO}_{2}$ retrieved from the Ozone Monitoring Instrument: Intercomparison, diurnal cycle, and trending. J. Geophys. Res. Atmos. 2011, 116. [CrossRef]

13. Jeong, U.; Kim, J.; Ahn, C.; Torres, O.; Liu, X.; Bhartia, P.K.; Spurr, R.J.; Haffner, D.; Chance, K.; Holben, B.N. An optimal-estimation-based aerosol retrieval algorithm using OMI near-UV observations. Atmos. Chem. Phys. 2016, 16, 177-193. [CrossRef]

14. Shimizu, A.; Sugimoto, N.; Matsui, I.; Arao, K.; Uno, I.; Murayama, T.; Kagawa, N.; Aoki, K.; Uchiyama, A.; Yamazaki, A. Continuous observations of Asian dust and other aerosols by polarization lidars in China and Japan during ACE-Asia. J. Geophys. Res. Atmos. 2004, 109. [CrossRef]

15. Kim, S.W.; Yoon, S.C.; Kim, J.; Kim, S.Y. Seasonal and monthly variations of columnar aerosol optical properties over east Asia determined from multi-year MODIS, LIDAR, and AERONET Sun/sky radiometer measurements. Atmos. Environ. 2007, 41, 1634-1651. [CrossRef]

16. Hayasaka, T.; Satake, S.; Shimizu, A.; Sugimoto, N.; Matsui, I.; Aoki, K.; Muraji, Y. Vertical distribution and optical properties of aerosols observed over Japan during the Atmospheric Brown Clouds-East Asia Regional Experiment 2005. J. Geophys. Res. Atmos. 2007, 112. [CrossRef]

17. Noh, Y.M. Single-scattering albedo profiling of mixed Asian dust plumes with multi wavelength Raman lidar. Atmos. Environ. 2014, 95, 305-317. [CrossRef]

18. Jethva, H.; Torres, O.; Ahn, C. Global assessment of OMI aerosol single-scattering albedo using ground-based AERONET inversion. J. Geophys. Res. Atmos. 2014, 119, 9020-9040. [CrossRef]

19. Spurr, R.; Wang, J.; Zeng, J.; Mishchenko, M.I. Linearized T-matrix and Mie scattering computations. J. Quant. Spectrosc. Radiat. Transf. 2012, 113, 425-439. [CrossRef] 
20. Mishchenko, M.I.; Travis, L.D.; Kahn, R.A.; West, R.A. Modeling phase functions for dustlike tropospheric aerosols using a shape mixture of randomly oriented polydisperse spheroids. J. Geophys. Res. Atmos. 1997, 102, 16831-16847. [CrossRef]

21. Koelemeijer, R.B.A.; De Haan, J.F.; Stammes, P. A database of spectral surface reflectivity in the range 335-772 nm derived from 5.5 years of GOME observations. J. Geophys. Res. Atmos. 2003, 108. [CrossRef]

22. Dietz, A.J.; Kuenzer, C.; Gessner, U.; Dech, S. Remote sensing of snow-a review of available methods. Int. J. Remote Sens. 2012, 33, 4094-4134. [CrossRef]

23. Boersma, K.F.; Jacob, D.J.; Eskes, H.J.; Pinder, R.W.; Wang, J. Intercomparison of SCIAMACHY and OMI tropospheric $\mathrm{NO}_{2}$ columns: Observing the diurnal evolution of chemistry and emissions from space. J. Geophys. Res. Atmos. 2008, 113. [CrossRef]

24. Bey, I.; Jacob, D.J.; Yantosca, R.M.; Logan, J.A.; Field, B.D.; Fiore, A.M.; Li, Q.; Liu, H.Y.; Mickley, L.J.; Schultz, M.G. Global modeling of tropospheric chemistry with assimilated meteorology: Model description and evaluation. J. Geophys. Res. Atmos. 2001, 106, 23073-23095. [CrossRef]

25. Park, R.J.; Jacob, D.J.; Field, B.D.; Yantosca, R.M.; Chin, M. Natural and transboundary pollution influences on sulfate-nitrate-ammonium aerosols in the United States: Implications for policy. J. Geophys. Res. Atmos. 2004, 109. [CrossRef]

26. Dubovik, O.; Sinyuk, A.; Lapyonok, T.; Holben, B.N.; Mishchenko, M.; Yang, P.; Eck, T.F.; Volten, H.; Munoz, O.; Veihelmann, B.; et al. Application of spheroid models to account for aerosol particle nonsphericity in remote sensing of desert dust. J. Geophys. Res. Atmos. 2006, 111. [CrossRef]

27. Ahn, C.; Torres, O.; Jethva, H. Assessment of OMI near-UV aerosol optical depth over land. J. Geophys. Res. Atmos. 2014, 119, 2457-2473. [CrossRef]

28. Valks, P.; Loyola, D.; Hao, N.; Rix, M.; Slijkhuis, S. Algorithm Theoretical Basis Document for GOME-2 Total Column Products of Ozone, Minor Trace Gases and Cloud Properties (GDP 4.2 for O3M-SAF OTO and NTO); DLR/GOME-2/ATBD; Deutsches Zentrum für Luft und Raumfahrt: Oberpfaffenhofen, Germany, 2008; Volume 1, p. 36.

29. Bucsela, E.J.; Krotkov, N.A.; Celarier, E.A.; Lamsal, L.N.; Swartz, W.H.; Bhartia, P.K.; Boersma, K.F.; Veefkind, J.P.; Gleason, J.F.; Pickering, K.E. A new stratospheric and tropospheric $\mathrm{NO}_{2}$ retrieval algorithm for nadir-viewing satellite instruments: Applications to OMI. Atmos. Meas. Tech. 2013, 6, 2607. [CrossRef]

(C) 2017 by the authors. Licensee MDPI, Basel, Switzerland. This article is an open access article distributed under the terms and conditions of the Creative Commons Attribution (CC BY) license (http:/ / creativecommons.org/licenses/by/4.0/). 